\title{
PENGARUH EFIKASI DIRI DAN KONTEN INSTAGRAM TERHADAP MINAT MENGAKSES PORTAL RUMAH BELAJAR KEMDIKBUD
}

\author{
Febri Nurhandayani \\ Institut Komunikasi dan Bisnis LSPR \\ 16110200806@lspr.edu
}

\begin{abstract}
Abstrak: Tujuan dari penelitian ini yaitu mengetahui apa dan besarnya pengaruh efikasi diri dan konten Instagram Rumah Belajar terhadap minat mengakses portal Rumah Belajar Kemdikbud. Metode penelitian ini adalah kuantitatif dengan pengumpulan data dilakukan menggunakan kuesioner yang disebarkan kepada 100 responden yang mengikuti akun Instagram Rumah Belajar. Adapun temuan penelitian menyatakan terdapat pengaruh yang positif dan signifikan secara parsial pada efikasi diri dan konten Instagram terhadap minat mengakses portal Rumah Belajar, dan terdapat pengaruh secara simultan dan signifkan antara efikasi diri dan konten Instagram Rumah Belajar terhadap minat mengakses portal Rumah Belajar dengan nilai kontribusi sebesar 56,8\%.
\end{abstract}

Kata Kunci: Efikasi Diri, Konten Instagram, Minat Mengakses

\begin{abstract}
The purpose of this study was to determine whether there is an effect and how muct the effect of selfefficacy and Instagram Content of Rumah Belajar towards the interest to access the Kemdikbud Rumah Belajar website. The research method used is quantitative and the data was collected by using a questionnaire distributed to 100 respondents who followed the Rumah Belajar Instagram account. The research findings state that there is a positive and partially significant effect on self-efficacy and Instagram content on interest in accessing the portal, and there is an effect on self-efficacy and Instagram content simultaneously on interest in accessing the portal with a contribution value of $56,8 \%$.
\end{abstract}

Keywords:. Self-Efficacy, Instagram Content, Interest to Access

\section{PENDAHULUAN}

Memasuki era revolusi industri pada generasi 4.0 yang ditandai dengan meningkatnya konektivitas, interaksi serta perkembangan sistem digital, kecerdasan artifisial, dan virtual (Risdianto, 2019). Dengan semakin konvergennya batas antara manusia, mesin dan teknologi informasi dan komunikasi tentu berimbas pula pada berbagai sektor kehidupan. Salah satunya yakni berdampak terhadap sistem pendidikan di Indonesia. Perubahan era ini tidak dapat dihindari oleh siapapun sehingga dibutuhkan penyiapan sumber daya manusia (SDM) yang memadai agar siap menyesuaikan dan mampu bersaing dalam skala global (Nia Safitri, 2019). Peningkatan kualitas SDM melalui jalur pendidikan mulai dari pendidikan dasar dan menengah hingga ke perguruan tinggi adalah kunci untuk mampu mengikuti perkembangan Revolusi Industri 4.0 (Yusnaini \& Slamet, 2019). Pendidikan 4.0 adalah respons terhadap kebutuhan revolusi industri 4.0 di mana manusia dan teknologi diselaraskan untuk menciptakan peluang-peluang baru dengan kreatif dan inovatif.

Dengan perkembangan zaman saat ini, maka semakin berkembangnya juga cara orang untuk mendapatkan pendidikan. Semakin berkembang sistem pendidikan yang bisa diakses dengan lebih fleksibel maka akan lebih memudahkan peserta didik untuk mendapat pendidikan dengan jenis pendidikan nonformal dan informal (Nilasari, 2020). Pendidikan nonformal sangat mendukung efikasi diri pada peserta didik seperti menempuh pembelajaran tambahan melalui bimbingan belajar dengan institusiinstitusi yang menyediakan les pelajaran yang berbayar dan ada pula yang menempuh dengan melalui belajar mandiri secara gratis (Agussani, 2020).

Oleh karena itu pemerintah Indonesia melalui Kemdikbud hadir di tengah-tengah 
peserta didik dan memberi pengertian bahwa banyaknya usaha di bidang pendidikan di Indonesia dan terus meningkat di setiap tahunnya menjadikan para peserta didik harus bijak dalam memilih bimbingan belajar. Dan dengan sistem teknologi yang semakin berkembang dan canggih pula menjadikan pilihan bimbingan belajar tidak hanya bisa ditempuh melalui offline tetapi dengan online. Pemerintah Indonesia, Kemdikbud, terus mengupayakan membuat program pendidikan selain dari pendidikan formal. Indonesia yang mulai memasuki dan menerapkan era revolusi industri 4.0 dimana teknologi dan informasi dikemas dalam suatu mesin yang terautomatisasi sehingga memudahkan orang untuk mengakses segala hal. Melihat kebijakan dari Kemenperin maka Kemdikbud membuat sebuah program yang mendukung maju Making Indonesia 4.0 dan proyek infrastruktur konektivitas internet yang hampir merata di berbagai daerah Indonesia (Doni, 2019), dengan perkembangan teknologi yang semakin canggih sehingga dibuatlah portal "Rumah Belajar Kemdikbud" sebuah bimbingan belajar online gratis yang berisikan konten bahan pembelajaran yang bertujuan untuk membantu para peserta didik mulai dari jenjang Pendidikan Anak Usia Dini (PAUD) hingga Sekolah Menengah Atas atau Kejuruan (SMA/SMK) (Kemdikbud, n.d.).

Pengguna bisa mencari di internet dengan kata kunci "Rumah Belajar Kemdikbud" atau langsung mengetik portal https://belajar.kemdikbud.go.id/. Dengan sekali mengklik, pengguna langsung disuguhkan dengan halaman depan yang berisikan tentang, fitur utama, testimoni, partner dan bantuan terhadap portal Rumah Belajar. Portal Rumah Belajar menyediakan konten bahan belajarnya dalam bentuk yang interaktif dengan alat-alat pendukung, seperti gambar, animasi, video, simulasi dan bentuk buku digital. Dari simulasisimulasi yang ada didalam portal Rumah Belajar membuktikan bahwa Kemdikbud sudah menerapkan revolusi industri 4.0 dimana dapat dilihat dari penggunaan simulasi juga penggunaan AI (Artificial Intelegence) yang merupakan teknologi komputer yang dibuat selayaknya seperti kecerdasan manusia, system integration yang berfungsi mempersatukan sistem, big data yang menyimpan seluruh data pengguna mulai dari identitas diri hingga memori akan apa saja yang sudah di akses dalam fitur dan lain sebagainya di dalam fitur-fitur portal Rumah Belajar Kemdikbud. Rumah Belajar menggunakan orang terpilih dari masing-masing 34 Provinsi di Indonesia yang akan ditunjuk sebagai Duta Rumah Belajar yang akan membantu Pusat Teknologi Informasi dan Komunikasi Pendidikan dan Kebudayaan (Pustekkom) Kemdikbud untuk memberikan sosialisasi kegunaan portal Rumah Belajar sebagai media belajar yang berbasis Teknologi Informasi dan Komunikasi (TIK) (Kemdikbud, n.d.) dan minat mengakses portal Rumah Belajar.

Dengan di berikan kemudahan dalam mengakses Pendidikan tambahan, tujuan Kemdikbud akan tersukseskan apabila setiap individu yang memilikikeinginan untuk mengakses portal tersebut. Yang mana Kebanyakan peserta didik yang menempuh pendidikan formal akan mempunyai efikasi diri. Yusuf dan Nurihsan (dikutip dalam Suwartini, 2016, p.41) menyatakan "efikasi diri sebagai keyakinan diri (sikap percaya diri) terhadap kemampuan sendiri untuk menampilkan tingkah laku yang akan mengarahkannya kepada hasil yang diharapkan". Efikasi diri yang tinggi ini penting dimiliki untuk menambah rasa percaya diri dalam diri peserta didik akan persepsi dirinya untuk bisa lulus dari sekolah dengan nilai yang baik dan maksimal.

Konsep efikasi diri berkaitan dengan prestasi peserta didik dimana yang mempunyai efikasi diri tinggi akan mempunyai kepercayaan diri bahwa dia akan mampu untuk mencapai hasil yang maksimal. Ormrod menjelaskan bahwa "self efficacy refers to learners' beliefs about their competence in a specific activity or domain" (2016, p. 130) yang berarti efikasi diri dimaksudkan bahwa keyakinan peserta didik 
akan kemampuannya di dalam suatu aktifitas tertentu. Efikasi diri memiliki peran penting dalam menumbuhkan minat karena semakin tinggi efikasi dirinya maka semakin tinggi minat seseorang dalam melakukan hal tersebut dengan kemampuannya.

Maka demi mngupayakan tujuan program Kemdikbud maka pemerintah mencari cara untuk meningkatkan minat peserta didik untuk mengakses atau menggunakan portal Rumah Belajar, kemendikbut mengetahui bahwa dorongan yang kuat dan memotivasi yang dipengaruhi oleh suatu faktor atau faktor lainnya untuk memilih atau menggunakan produk sebagai suatu tindakan. Faktor-faktor yang mempengaruhi minat menurut Reber (dikutip dalam Syah, 2009): a. faktor internal dan. b. faktor eksternal. Schiffman dan Kanuk (dikutip dalam Cahyono, Kusumawati, \& Kumadji, 2016, p. 151) menyebutkan dimensi minat beli dijelaskan oleh beberapa komponen, yaitu: a. Tertarik untuk mencari informasi tentang produk, b. Mempertimbangkan untuk membeli, c. Tertarik untuk mencoba, d. Ingin mengetahui produk, e. Ingin memiliki produk.

Dilihat portal Rumah Belajar yang menyediakan konten bahan belajarnya yang interaktif, akses yang gratis dan bisa digunakan dimana saja dan kapanpun bisa menjadikan Rumah Belajar pilihan minat utama sebagai bimbingan belajar yang mendukung efikasi diri para peserta didik dengan membentuk sebuah persepsi dari para peserta didik terhadap portal Rumah Belajar dalam bentuk konten pada media sosial Instagram.

Instagram menjadi salah satu media sosial yang dapat dimanfaatkan sebagai media pemasaran langsung dan berinteraksi dengan konsumen dengan fitur utama yang menyajikan berupa penampilan suatu konten/informasi/hal yang menarik secara visual yaitu berupa foto dan video singkat berdurasi sekitar 1 menit. Pengguna aktif Instagram yang setiap tahunnya meningkat menjadikan Instagram sebagai media pendukung atau promosi yang tepat untuk portal Rumah Belajar dan/atau produk lainnya.
Dimulai dari fitur utama yang menampilkan konten secara visual berupa foto dan video, pengguna yang cukup banyak dan aktif di Indonesia, gratis digunakan bagi pengguna dan pengoperasian aplikasi yang cukup mudah bagi pengguna Instagram.

Melihat bahwa para peserta didik yang sangat membutuhkan pendidikan non-formal berupa bimbingan belajar untuk meningkatkan efikasi dirinya sebagai faktor internal dan pengenalan portal atau promosi melalui konten pada akun Instagram Rumah Belajar sebagai faktor eksternal dapat memberi pengaruh terhadap minat mengakses portal Rumah Belajar dengan fitur-fitur yang sudah disediakan oleh Kemdikbud. Portal Rumah Belajar yang dibuat secara khusus dan gratis untuk para peserta didik dan guru dimaksudkan untuk menjadi pilihan utama dan membantu proses bimbingan belajar tambahan sehingga mendorong peserta didik untuk mendapatkan hasil dan dapat lulus dengan maksimal.

Berdasarkan uraian di atas maka peneliti tertarik untuk mengkaji lebih dalam tentang "Pengaruh Efikasi Diri dan Konten Instagram terhadap Minat Mengakses Portal Rumah Belajar Kemdikbud" yang memiliki tujuan untuk mengetahui apa dan besarnya pengaruh efikasi diri, konten Instagram terhadap minat mengakses portal Rumah Belajar Kemdikbud, baik setiap variable ataupun secara bersamasama.

\section{KAJIAN TEORI \\ Minat Mengakses}

Minat merupakan rasa ketertarikan pada sesuatu tanpa adanya unsur pemaksaan dari pihak lain. Kartika et al. (2019) menyatakan minat adalah suatu rasa lebih suka dan rasa keterikatan pada suatu hal atau aktivitas. Menurut Indika \& Jovita (2017) mengatakan bahwa minat beli dipengaruhi oleh media sosial yang dilakukan melalui persepi konsumen terhadap produk. Dikaitkan minat beli dengan minat mengakses atau menggunakan portal Rumah Belajar Kemdikbud sehingga bisa ditarik pengertian bahwa dorongan yang kuat dan 
memotivasi yang dipengaruhi oleh suatu faktor atau faktor lainnya untuk memilih atau menggunakan produk sebagai suatu tindakan.

Dari pernyataan Evaliana (2015) di atas maka peneliti mensintensiskan bahwa faktor-faktor yang mempengaruhi minat untuk mengakses portal Rumah Belajar Kemdikbud ialah:

1. Faktor internal dimana dorongan dari dalam diri sendiri sehingga menimbulkan minat mengakses. Dalam penelitian ini faktor internal yang mempengaruhi minat ialah efikasi diri, keyakinan diri akan keberhasilan yang ingin dicapai.

2. Faktor eksternal dimana dorongan yang berasal dari luar diri. Dalam penelitian ini konten Instagram Rumah Belajar menjadi faktor eksternal dalam mempengaruhi minat mengakses portal Rumah Belajar.

Tabel 1. Faktor-Faktor yang Mempengaruhi Minat untuk Mengakses Portal Rumah Belajar Kemdikbud

\begin{tabular}{lll}
\hline \multicolumn{1}{c}{ Variable } & \multicolumn{1}{c}{ Dimensi } & \multicolumn{1}{c}{ Indikator } \\
\hline $\begin{array}{l}\text { Minat Mengakses Portal } \\
\text { Schiffman dan Kanuk } \\
\text { dikutip dalam Cahyono, }\end{array}$ & $\begin{array}{l}\text { Tertarik untuk mencari } \\
\text { informasi tentang portal } \\
\text { Kusumawati, \& Kumadji } \\
(2016)\end{array}$ & $\begin{array}{l}\text { Menciptakan komunikasi supaya } \\
\text { konsumen sadar akan produk }\end{array}$ \\
& $\begin{array}{l}\text { Mempertimbangkan untuk } \\
\text { mengakses portal }\end{array}$ & $\begin{array}{l}\text { Komunikasi informasi produk } \\
\text { supaya konsumen memiliki } \\
\text { pengetahuan atas produk }\end{array}$ \\
\cline { 2 - 3 } & Tertarik untuk mencoba portal & $\begin{array}{l}\text { Menimbulkan rasa suka konsumen } \\
\text { terhadap produk supaya terdapat } \\
\text { keinginan untuk membeli }\end{array}$ \\
\cline { 2 - 4 } & Ingin mengetahui portal & $\begin{array}{l}\text { Perbandingan produk menurut } \\
\text { kemasan, kualitas, nilai, performa, } \\
\text { dan lain sebagainya }\end{array}$ \\
\cline { 2 - 4 } & Ingin mengakses portal & $\begin{array}{l}\text { Meyakinkan konsumen dan } \\
\text { menimbulkan minat beli konsumen } \\
\text { untuk membeli }\end{array}$ \\
\hline
\end{tabular}

\section{Efikasi Diri}

Efikasi diri sebagai "people's belief in their capability to exercise some measure of control over their own functioning and over environmental events" (Khotimah et al., 2016). Konsep efikasi diri adalah faktor kognitif yang ditekankan dalam model pembelajaran di teori kognitif sosial oleh Albert Bandura, yakni keyakinan bahwa seseorang bisa menguasai situasi dan menghasilkan hasil positif. Yang mana dapat dimengerti bahwa efikasi diri adalah keyakinan seseorang akan kemampuannya dalam menghadapi suatu situasi untuk mendapat hasil yang maksimal.faktor-faktor efikasi diri dapat diperoleh, ditingkatkan atau mengalami penurunan karena pengalaman sebelumnya, keberhasilan dan kegagalan teman atau rekan sebaya, persuasi sosial, kondisi fisik dan emosional (Prastihastari Wijaya, 2012).

Table 2. Faktor-Faktor Efikasi Diri

\begin{tabular}{lll}
\hline \multicolumn{1}{c}{ Variabel } & Dimensi & \multicolumn{1}{c}{ indikator } \\
\hline Efikasi Diri (X1) & Level & Menghadapi rintangan sebaik mungkin \\
Bandura dikutip & & Tidak mudah menyerah saat menghadapi persoalan yang \\
dalam Feist dan Feist & & sulit \\
\hline
\end{tabular}


(2010, p. 212) Strength Selalu bersemangat mencapai hasil yang maksimal Optimis dalam mengerjakan sesuatu

$\begin{array}{ll}\text { generality } & \text { Seberapa yakin terhadap kemampuannya dalam } \\ \text { mengerjakan persoalan } \\ \text { Mengevaluasi diri untuk menjadi lebih baik } \\ \text { Saat kegagalan datang maka akan bangkit lagi } \\ \text { Siap menghadapi resiko } \\ \text { Bertanggung jawab atas segala sesuatu yang dilakukan } \\ \text { Melakukan perencaan akan segala sesuatu yang ingin } \\ \text { dicapai }\end{array}$

\section{Konten Instagram}

media sosial dapat diartikan media yang menggunakan internet sebagai sistemnya, adanya kemudahan dalam terkoneksi satu sama lain dan media berbagi pesan dengan membagi konten berupa teks, audio, foto dan video (Wahyuni et al., 2019). Jenis media social itu berbagai macam, dalam penelitian ini menggunaka media Instagram. Instagram menjadi salah satu media sosial yang dapat dimanfaatkan sebagai media pemasaran langsung dan berinteraksi dengan konsumen. Karakteristik yang dimiliki Instagram adalah efek filter, berbagi foto tidak hanya di Instagram tetapi juga terakses ke Facebook, Twitter, Flickr dan Tumblr, waktu upload foto yang cepat, format tampilan dalam bentuk persegi, konsep follow, like, comment, hashtag, video berdurasi paling lama 1 menit, live story dan saat ini ada program IGTV untuk video yang berdurasi lebih dari 1 menit (Wahyudin \& Adiputra, 2019).

Konten dapat di artikan sebagai segala sesuatu yang menambah nilai bagi kehidupan pembaca. Konten yang bagus adalah menambahkan nilai ke khalayak dan adanya percakapan online (Shafira \& Ira, 2020).

Table 3. Konten Instagram

\begin{tabular}{|c|c|c|c|}
\hline & Variable & Dimensi & Indikator \\
\hline \multirow[t]{3}{*}{$\begin{array}{l}\text { Konten } \\
\text { Social } \\
\text { (2016); }\end{array}$} & $\begin{array}{l}\text { Instagram The } \\
\text { Media Guru }\end{array}$ & Valuable & $\begin{array}{l}\text { Upload Foto; Foto menarik } \\
\text { Upload Video; Video Menarik } \\
\text { Caption yang informatif; Bahasa dan Isi pesan dipahami } \\
\text { pengguna } \\
\text { Hashtag yang digunakan } \\
\text { Tatanan feeds yang rapi, kreatif, aesthetic, dan menarik }\end{array}$ \\
\hline & & Relevant & $\begin{array}{l}\text { Target khalayak menyukai postingan } \\
\text { Target khalayak mengomentari postingan } \\
\text { Relevansi informasi yang dapat dipercaya, actual, informatif } \\
\text { dan menarik } \\
\text { Instagram story berkaitan dengan informasi akun dan } \\
\text { pengguna }\end{array}$ \\
\hline & & Consistent & $\begin{array}{l}\text { Posting foto yang berkala. } \\
\text { Feed konten bertambah dan adanya kesan keestetikaan }\end{array}$ \\
\hline
\end{tabular}

\section{METODE PENELITIAN}

Penelitian ini menggunakan metode penelitian kuantitatif. Mulyadi (2012) menyatakan bahwa penelitian kuantitatif adalah 
metode penelitian yang mempunyai tujuan menggambarkan sebuah fenomena atau gejala sosial yang terjadi di masyarakat dimana fenomena saling berhubungan satu sama lain. Metode pengumpulan data pada penelitian ini adalah berupa kuesioner atau angket dimana menurut Suyitno (2020) menjelaskan bahwa metode angket atau questionnaire merupakan serangkaian atau daftar pertanyaan yang disusun secara sistematis, kemudian dikirim untuk diisi oleh responden.

Penelitian ini merupakan jenis penelitian eksplanatif kausalitas, dimana Sudaryono et al. (2018) menyatakan bahwa penelitian eksplanasi bertujuan untuk mendeskripsikan suatu generalisasi atau menjelaskan hubungan antara satu variabel dengan variabel lainnya hubungan sebab akibat. Oleh karena itu peneliti ingin mengetahui pengaruh atau sebab-akibat antara efikasi diri dan konten Instagram Rumah Belajar terhadap minat mengakses portal Rumah Belajar Kemdikbud.

Populasi yang digunakan dalam penelitian ini adalah total pengikut akun media sosial Instagram Rumah Belajar @belajar.kemdikbud sebesar 9.907 pengikut terhitung dari bulan Oktober 2018 hingga Oktober 2019 dan tetapi mengalami kelonjakan setelah pandemik COVID-19 menjadi sebanyak 30.000 pengikut pada Juni 2020 (Rumah Belajar, n.d.). Pengikut akun media sosial Instagram Rumah Belajar diyakini mengetahui portal Rumah Belajar Kemdikbud. ukuran sampel berjumlah minimal 99,66. Maka peneliti membulatkan jumlah sampel menjadi 100 orang dari pengikut akun media sosial Instagram Rumah Belajar. Dengan batasan kriteria responden diantaranya:

1. Followers akun Instagram Rumah Belajar @ belajar.kemdikbud

2. Pelajar SMA/SMK

3. Tertarik dengan portal Rumah Belajar Kemdikbud

\section{HASIL DAN PEMBAHASAN}

Uji Validitas
Tabel 4. Uji Validitas

\begin{tabular}{|c|c|c|c|}
\hline Item & $\begin{array}{l}\text { Corrected } \\
\text { Item-Total } \\
\text { Correlation } \\
\text { (R Hitung) }\end{array}$ & $\begin{array}{c}\mathrm{R} \\
\text { Tabel }\end{array}$ & Ket \\
\hline PTY1_X1 & 0,684 & 0,1654 & VALID \\
\hline PTY2_X1 & 0,519 & 0,1654 & VALID \\
\hline PTY3_X1 & 0,670 & 0,1654 & VALID \\
\hline PTY4_X1 & 0,649 & 0,1654 & VALID \\
\hline PTY5_X1 & 0,601 & 0,1654 & VALID \\
\hline PTY6_X1 & 0,665 & 0,1654 & VALID \\
\hline PTY7_X1 & 0,714 & 0,1654 & VALID \\
\hline PTY8_X1 & 0,551 & 0,1654 & VALID \\
\hline PTY9_X1 & 0,596 & 0,1654 & VALID \\
\hline PTY10_X1 & 0,497 & 0,1654 & VALID \\
\hline PTY11_X1 & 0,367 & 0,1654 & VALID \\
\hline PTY12_X1 & 0,397 & 0,1654 & VALID \\
\hline PTY1_X2 & 0,829 & 0,1654 & VALID \\
\hline PTY2_X2 & 0,671 & 0,1654 & VALID \\
\hline PTY3_X2 & 0,628 & 0,1654 & VALID \\
\hline PTY4_X2 & 0,660 & 0,1654 & VALID \\
\hline PTY5_X2 & 0,770 & 0,1654 & VALID \\
\hline PTY6_X2 & 0,654 & 0,1654 & VALID \\
\hline PTY7_X2 & 0,748 & 0,1654 & VALID \\
\hline PTY8_X2 & 0,737 & 0,1654 & VALID \\
\hline PTY9_X2 & 0,741 & 0,1654 & VALID \\
\hline PTY10_X2 & 0,642 & 0,1654 & VALID \\
\hline PTY11_X2 & 0,674 & 0,1654 & VALID \\
\hline PTY12_X2 & 0,559 & 0,1654 & VALID \\
\hline PTY13_X2 & 0,384 & 0,1654 & VALID \\
\hline PTY14_X2 & 0,804 & 0,1654 & VALID \\
\hline PTY15_X2 & 0,763 & 0,1654 & VALID \\
\hline PTY16_X2 & 0,708 & 0,1654 & VALID \\
\hline PTY17_X2 & 0,777 & 0,1654 & VALID \\
\hline PTY18_X2 & 0,722 & 0,1654 & VALID \\
\hline PTY19_X2 & 0,709 & 0,1654 & VALID \\
\hline PTY20_X2 & 0,685 & 0,1654 & VALID \\
\hline PTY1_Y & 0,532 & 0,1654 & VALID \\
\hline PTY2_Y & 0,669 & 0,1654 & VALID \\
\hline PTY3_Y & 0,765 & 0,1654 & VALID \\
\hline
\end{tabular}




\begin{tabular}{llll}
\hline PTY4_Y & 0,744 & 0,1654 & VALID \\
\hline PTY5_Y & 0,748 & 0,1654 & VALID \\
\hline PTY6_Y & 0,786 & 0,1654 & VALID \\
\hline PTY7_Y & 0,760 & 0,1654 & VALID \\
\hline PTY8_Y & 0,760 & 0,1654 & VALID \\
\hline PTY9_Y & 0,722 & 0,1654 & VALID \\
\hline PTY10_Y & 0,633 & 0,1654 & VALID \\
\hline PTY11_Y & 0,766 & 0,1654 & VALID \\
\hline
\end{tabular}

\begin{tabular}{lll} 
Minat & 0,927 & 11 \\
Mengakses & & \\
Portal & & \\
\hline
\end{tabular}

Kuesioner ini disebarkandengan 12 butir pernyataan yang dinyatakan valid pada pre-test kepada 100 responden. Kuesioner ini dinyatakan valid dengan membandingkan nilai $\mathrm{r}$ hitung (corrected item-total correlation) dengan nilai $\mathrm{r}$ tabel. Responden yang berjumlah 100, dan dari pernyataan Siregar (2013) bila kolerasi tiap faktor positif dan mempunyai besar $\geq$ dari 0,3 maka instrumen tersebut dinyatakan valid.

Maka dari tabel hasil uji validitas variabel X1 (efikasi diri) di atas, nilai $r$ hitung $>$ (lebih besar dari) $r$ tabel dan nilai koefisien korelasi tiap faktor melebihi 0,3 sehingga instrumen penelitian pada variabel Efikasi Diri dinyatakan valid. Dari tabel hasil uji validitas variabel X2 (konten Instagram) di atas, nilai $r$ hitung > (lebih besar dari) 0,3 sehingga instrumen penelitian pada variabel Konten Instagram dinyatakan valid. Dari tabel hasil uji validitas variabel Y (minat mengakses portal) di atas, nilai $\mathrm{r}$ hitung > (lebih besar dari) 0,3 sehingga instrumen penelitian pada variabel minat mengakses portal dinyatakan valid.

\section{Uji Reliabilitas}

\begin{tabular}{|c|c|c|}
\hline \multicolumn{3}{|c|}{ Tabel 5. Uji Rehabilitas } \\
\hline \multirow[t]{2}{*}{ Variabel } & \multicolumn{2}{|c|}{ Reliability Statistic } \\
\hline & $\begin{array}{c}\text { Cronbach's } \\
\text { Alpha }\end{array}$ & $\begin{array}{l}\mathrm{N} \text { of } \\
\text { Items }\end{array}$ \\
\hline $\begin{array}{l}\text { Efikasi } \\
\text { Diri }\end{array}$ & 0,879 & 12 \\
\hline $\begin{array}{l}\text { Konten } \\
\text { Instagram }\end{array}$ & 0,948 & 20 \\
\hline
\end{tabular}

Dari tabel hasil uji reliabilitas variabel X1 (efikasi diri) di atas, nilai Alpha Cronbach sebesar 0,879 > (lebih besar dari) 0,60 sehingga instrumen penelitian pada variabel X1 (efikasi diri) dalah reliable, konsisten, dan sangat tinggi. Hasil uji reliabilitas variabel X2 (konten Instagram) di atas, nilai Alpha Cronbach sebesar $0,948>$ (lebih besar dari) 0,60 sehingga instrumen penelitian pada variabel X2 (konten Instagram) adalah reliable, konsisten, dan sangat tinggi. Hasil uji reliabilitas pre-test variabel $\mathrm{Y}$ (minat mengakses portal) di atas, nilai Alpha Cronbach sebesar 0,927 > (lebih besar dari) 0,60 sehingga instrumen penelitian pada variabel $\mathrm{Y}$ (minat mengakses portal) adalah reliable, konsisten, dan sangat tinggi.

\section{Hasil Analisis Indikator}

Analisis Indikator ini dilakukan untuk menjelaskan instrumen penelitian pada variabel di setiap butir pernyataannya dengan menarik kesimpulan berdasarkan rata-rata jawaban responden dan dianalisa berdasarkan tabel kategori rata-rata jawaban responden.

Tabel 6. Kategori Rata-Rata Jawaban Responden

\begin{tabular}{ll}
\hline Interval Rata-Rata & \multicolumn{1}{c}{ Pernyataan } \\
\hline $1-1,80$ & Sangat Tidak Setuju \\
\hline $1,81-2,60$ & Tidak Setuju \\
\hline $2,61-3,40$ & Ragu-Ragu \\
\hline $3,41-4,20$ & Setuju \\
\hline $4,21-5,00$ & Sangat Setuju \\
\hline
\end{tabular}

Sumber: Evaliana (2015)

Tabel 7. Analisis Indikator Rata-Rata Variabel

$\begin{array}{lll} & \text { Rata- } & \\ \text { Pernyataan } & \text { Rata } & \text { Pernyataan } \\ & \text { Jawaban } & \end{array}$




\begin{tabular}{|c|c|c|}
\hline PTY1_X1 & 3,88 & Setuju \\
\hline PTY2_X1 & 3,81 & Setuju \\
\hline PTY3_X1 & 3,90 & Setuju \\
\hline PTY4_X1 & 3,77 & Setuju \\
\hline PTY5_X1 & 3,78 & Setuju \\
\hline PTY6_X1 & 3,81 & Setuju \\
\hline PTY7_X1 & 3,77 & Setuju \\
\hline PTY8_X1 & 3,99 & Setuju \\
\hline PTY9_X1 & 4,11 & Setuju \\
\hline PTY10_X1 & 4,31 & Sangat Setuju \\
\hline PTY11_X1 & 4,26 & Sangat Setuju \\
\hline PTY12_X1 & 4,36 & Sangat Setuju \\
\hline PTY1_X2 & 3,99 & Setuju \\
\hline PTY2_X2 & 3,95 & Setuju \\
\hline PTY3_X2 & 3,94 & Setuju \\
\hline PTY4_X2 & 4,00 & Setuju \\
\hline PTY5_X2 & 4,03 & Setuju \\
\hline PTY6_X2 & 3,93 & Setuju \\
\hline PTY7_X2 & 3,99 & Setuju \\
\hline PTY8_X2 & 4,04 & Setuju \\
\hline PTY9_X2 & 3,85 & Setuju \\
\hline PTY10_X2 & 3,90 & Setuju \\
\hline PTY11_X2 & 3,80 & Setuju \\
\hline PTY12_X2 & 3,74 & Setuju \\
\hline PTY13_X2 & 2,84 & RaguRagu \\
\hline PTY14_X2 & 3,82 & Setuju \\
\hline PTY15_X2 & 3,77 & Setuju \\
\hline PTY16_X2 & 3,83 & Setuju \\
\hline PTY17_X2 & 3,86 & Setuju \\
\hline PTY18_X2 & 3,57 & Setuju \\
\hline PTY19_X2 & 3,33 & Ragu-Ragu \\
\hline PTY20_X2 & 3,88 & Setuju \\
\hline PTY1_Y & 3,74 & Setuju \\
\hline PTY2_Y & 3,78 & Setuju \\
\hline PTY3_Y & 3,92 & Setuju \\
\hline PTY4_Y & 4,00 & Setuju \\
\hline PTY5_Y & 4,24 & SangatSetuju \\
\hline
\end{tabular}

\begin{tabular}{lll}
\hline PTY6_Y & 4,22 & Sagat Setuju \\
\hline PTY7_Y & 4,17 & Setuju \\
\hline PTY8_Y & 4,04 & Setuju \\
\hline PTY9_Y & 4,19 & Setuju \\
\hline PTY10_Y & 3,81 & Setuju \\
\hline PTY11_Y & 4,38 & Sangat Setuju \\
\hline
\end{tabular}

Dari tabel di atas, rata-rata responden setuju dengan pernyataan-pernyataan instrumen penelitian variabel X1 (Efikasi Diri) di atas dengan diperolehnya rata-rata hasil jawaban responden bernilai 3,97. Hal ini berarti rata-rata responden setuju bahwa responden mempunyai efikasi diri dengan percaya, tidak mudah menyerah, optimis dan bertanggung jawab pada dirinya sendiri. Responden juga setuju bahwa jika dengan mengakses portal Rumah Belajar dapat mengerjakan persoalan dan optimis dalam belajar. Sejalan dengan dimensi efikasi diri oleh Bandura (dalam Feist dan Feist, 2010) dimana ada dimensi tingkat (level) yaitu tingkah laku individu dirasa mampu dilakukannya atau keyakinan pada tindakan yang dilakukan, dimensi kekuatan (strength) yaitu keyakinan individu mengenai kemampuannya untuk bertahan atau tidak mudah menyerah, dan dimensi generalisasi (generality) yaitu individu merasa yakin terhadap kemampuannya dan berani bertanggung jawab pada dirinya sendiri.

Dari tabel di atas, dapat disimpulkan bahwa rata-rata responden setuju atas pernyataanpernyataan dari instrumen penelitian variabel X2 (Konten Instagram), hal tersebut dapat dilihat dari rata-rata hasil jawaban responden bernilai 3,80. Responden setuju bahwa konten Instagram akun Rumah Belajar mempunyai konten yang menarik, informatif, dan bermanfaat bagi dirinya. Adapun responden menjawab ragu-ragu terhadap pernyataan untuk mengomentari foto/video yang diunggah dan sering melihat Instagram Story Rumah Belajar yang berarti responden merasa belum terlibat untuk ikut berkomentar dan melihat atau menonton story Instagram Rumah Belajar. Jawaban responden 
ini sesuai dengan dimensi konten Instagram yang dirumuskan oleh peneliti, dimensi valuable yaitu responden setuju konten yang diunggah Rumah Belajar bermanfaat sehingga responden memerhatikan konten yang ada, dimensi relevant yaitu responden setuju pada pernyataan relevansi informasi yang ada di dalam konten yang diuggah dapat dipercaya, aktual, informatif dan menarik, dan dimensi consistent yaitu dimana responden setuju akan pernyataan bahwa Instagram Rumah Belajar membuat dan mempublikasikan kontennya secara konsisten sehingga responden selalu menerima informasiyang baru.

Dari tabel di atas, rata-rata responden setuju dengan pernyataan-pernyataan instrumen penelitian variabel Y (Minat Mengakses Portal) di atas dengan diperolehnya rata-rata hasil jawaban responden bernilai 4,04. Schiffman \& Kanuk (dalam Cahyono, Kusumawati, \& Kumadji, 2016, p. 151) menyebutkan dimensi minat beli sebagai tertarik untuk mencari informasi tentang produk, mempertimbangkan untuk membeli, tertarik untuk mencoba, ingin mengetahui produk, ingin menggunakan produk dan hasil jawaban responden menyatakan setuju pada instrumen penelitian ini. Adapun responden menyatakan pernyataan sangat setuju bahwa responden tertarik untuk mengakses portal Rumah Belajar karena merupakan bimbingan online yang gratis, kemudahan untuk mengakses dimana saja dan kapan pun, dan portal Rumah Belajar sangat membantu saat pandemik COVID-19.

\section{Analisis Koefisien Korelasi}

Tabel 8. Analisis Koefisien Korelasi Variabel Efikasi Diri (X1) terhadap Minat Mengakses

\begin{tabular}{|c|c|c|c|}
\hline \multicolumn{4}{|c|}{ Portal (Y) } \\
\hline \multicolumn{4}{|c|}{ Correlations } \\
\hline & & $\mathrm{X} 1$ & $\mathrm{Y}$ \\
\hline \multirow[t]{3}{*}{$\mathrm{X} 1$} & $\begin{array}{l}\text { Pearson } \\
\text { Correlation }\end{array}$ & 1 & $.569 * *$ \\
\hline & $\begin{array}{l}\text { Sig. (2- } \\
\text { tailed) }\end{array}$ & & .000 \\
\hline & $\mathrm{N}$ & 100 & 100 \\
\hline
\end{tabular}

\begin{tabular}{llll}
\hline $\mathrm{Y}$ & $\begin{array}{l}\text { Pearson } \\
\text { Correlation }\end{array}$ & $.569 * *$ & 1 \\
\cline { 2 - 3 } & $\begin{array}{l}\text { Sig. }(2- \\
\text { tailed) }\end{array}$ & .000 & \\
\cline { 2 - 3 } & $\mathrm{N}$ & 100 & 100 \\
\multicolumn{3}{l}{ *. Correlation is significant at the 0.01 level } \\
(2-tailed).
\end{tabular}

Dari tabel correlations di atas menunjukkan nilai $r$ hitung sebesar 0,569 dimana nilai ini lebih besar dari nilai $r$ tabel 0,1638 dan nilai signifikansi sebesar 0,000 yang lebih kecil dari nilai signifikansi 0,1 pada Efikasi Diri (X1) terhadap Minat Mengakses Portal (Y). Maka dapat disimpulkan bahwa terdapat hubungan atau korelasi parsial pada variabel X1 (Efikasi Diri) terhadap variabel $\mathrm{Y}$ (Minat Mengakses Portal). Nilai ini juga menunjukkan terdapat hubungan yang cukup kuat positif antara X1 dan Y dimana terjadi hubungan yang searah. Artinya bila X1 (Efikasi Diri) naik, maka Y (Minat Mengakses Portal) akan naik cukup signifikan.

Tabel. 9. Analisis Koefisien Korelasi Variabel Konten Instagram (X2) terhadap Minat Mengakses Portal (Y)

\begin{tabular}{llll}
\hline Correlations & & & \\
\hline & & $\mathrm{X} 2$ & $\mathrm{Y}$ \\
\hline $\mathrm{X} 2$ & $\begin{array}{l}\text { Pearson } \\
\text { Correlation }\end{array}$ & 1 & $.714^{* *}$ \\
\cline { 2 - 4 } & $\begin{array}{l}\text { Sig. (2- } \\
\text { tailed) }\end{array}$ & \\
\cline { 2 - 4 } & $\mathrm{N}$ & 100 & 100 \\
\hline $\mathrm{Y}$ & $\begin{array}{l}\text { Pearson } \\
\text { Correlation }\end{array}$ & $.714^{* *}$ & 1 \\
\cline { 2 - 4 } & $\begin{array}{l}\text { Sig. (2- } \\
\text { tailed) }\end{array}$ & .000 & \\
\cline { 2 - 4 } & $\mathrm{N}$ & 100 & 100 \\
\hline$* *$ Correlation is significant at the 0.01 level \\
(2-tailed).
\end{tabular}

Terdapat pula korelasi parsial pada variabel $\mathrm{X} 2$ (Konten Instagram) terhadap variabel $\mathrm{Y}$ (Minat Mengakses Portal) dengan nilai $r$ hitung sebesar 0,714 yang lebih besar dari nilai $r$ tabel 0,1638 dan nilai signifikansi sebesar 0,000 yang 
lebih kecil dari nilai signifikansi 0,1 . Nilai ini menunjukkan terdapat hubungan yang kuat positif antara X2 dan Y dimana terjadi hubungan yang searah. Artinya bila X2 (Konten Instagram) naik, maka Y (Minat Mengakses Portal) akan naik secara signifikan.

Tabel 10. Analisis Koefisien Korelasi Variabel Efikasi Diri (X1) dan Konten Instagram (X2) terhadap Minat Mengakses Portal (Y)

\begin{tabular}{|c|c|c|c|c|}
\hline \multicolumn{5}{|c|}{ Correlations } \\
\hline & & $\mathrm{X} 1$ & $\mathrm{X} 2$ & $\mathrm{Y}$ \\
\hline \multirow[t]{3}{*}{$\mathrm{X} 1$} & Pearson Correlation & 1 & $.504 * *$ & $.569 * *$ \\
\hline & Sig. (2-tailed) & & .000 & .000 \\
\hline & $\mathrm{N}$ & 100 & 100 & 100 \\
\hline \multirow[t]{3}{*}{$\mathrm{X} 2$} & Pearson Correlation & $.504 * *$ & 1 & $.714 * *$ \\
\hline & Sig. (2-tailed) & .000 & & .000 \\
\hline & $\mathrm{N}$ & 100 & 100 & 100 \\
\hline \multirow[t]{3}{*}{$\mathrm{Y}$} & Pearson Correlation & $.569 * *$ & $.714 * *$ & 1 \\
\hline & Sig. (2-tailed) & .000 & .000 & \\
\hline & $\mathrm{N}$ & 100 & 100 & 100 \\
\hline
\end{tabular}

Dari tabel correlations di atas menunjukkan nilai $r$ hitung sebesar 0,504 dimana nilai ini lebih besar dari nilai $r$ tabel 0,1638 dan nilai signifikansi sebesar 0,000 yang lebih kecil dari nilai signifikansi 0,1 . Maka dapat disimpulkan bahwa terdapat hubungan atau korelasi parsial pada variabel X1 (Efikasi Diri) dan variabel X2 (Konten Instagram) terhadap variabel Y (Minat Mengakses Portal). Nilai ini juga menunjukkan terdapat hubungan yang cukup kuat positif pada $\mathrm{X} 1, \mathrm{X} 2$, dan Y dimana terjadi hubungan yang searah. Artinya bila X1 (Efikasi Diri) naik

dan X2 (Konten Instagram) naik, maka Y (Minat Mengakses Portal) akan naik cukup signifikan

\section{Analisis Koefisien Determinasi}

Tabel 11. Analisis Koefisien Determinasi

\begin{tabular}{|c|c|c|c|c|}
\hline \multicolumn{5}{|c|}{ Model Summaryb } \\
\hline \multirow[t]{2}{*}{ Model } & $\mathrm{R}$ & R Square & Adjusted R Square & $\begin{array}{l}\text { Std. Error of the } \\
\text { Estimate }\end{array}$ \\
\hline & $754 \mathrm{a}$ &, 568 & ,559 & 4,28943 \\
\hline \multicolumn{5}{|c|}{ a. Dependent Variable: Minat Mengakses Portal } \\
\hline \multicolumn{5}{|c|}{ b. Predictors: (Constant), Efikasi Diri, Konten Instagram } \\
\hline
\end{tabular}

Korelasi (R) yang secara simultan (bersamasama) antara variabel X1 (Efikasi Diri) dan X2 (Konten Instagram) terhadap Y (Minat Mengakses Portal) diperoleh nilai sebesar 0,754. Nilai ini menunjukkan terdapat hubungan yang kuat positif antara X1, X2, dan Y dimana terjadi hubungan yang searah. Artinya bila X1 (Efikasi
Diri) dan X2 (Konten Instagram) naik, maka Y (Minat Mengakses Portal) akan naik secara signifikan. Adapun kontribusi atau sumbangan secara simultan yang diberikan oleh variabel X1 (Efikasi Diri) dan X2 (Konten Instagram) terhadap Y (Minat Mengakses Portal) mempunyai nilai sebesar $56,8 \%$ ( $\mathrm{R}$ Square), sedangkan sisanya $43,2 \%$ dipengaruhi oleh variabel lain. 


\section{Analisa Persamaan Regresi Berganda}

Tabel 12. Persamaan Regresi Berganda

\begin{tabular}{|c|c|c|c|c|c|c|}
\hline & & \multicolumn{2}{|c|}{ Unstandardized Coefficients } & \multicolumn{2}{|l|}{$\begin{array}{l}\text { Standardized } \\
\text { Coefficients }\end{array}$} & \multirow[b]{2}{*}{ Sig. } \\
\hline \multicolumn{2}{|c|}{ Model } & $\mathrm{B}$ & Std. Error & Beta & $\mathrm{t}$ & \\
\hline \multirow[t]{3}{*}{1} & (Constant) & 2,581 & 3,926 & & 657 &, 512 \\
\hline & Efikasi Diri (X1) & ,317 &, 087 & ,281 & 3,635 &, 000 \\
\hline & $\begin{array}{l}\text { Konten Instagram } \\
\text { (X2) }\end{array}$ & ,352 &, 048 &, 572 & 7,401 & ,000 \\
\hline
\end{tabular}

\section{A. Dependent Variable: Minat Mengakses Portal}

Dari tabel analisis regresi di atas, menunjukkan bahwa model persamaan regresi berganda untuk memperkirakan minat mengakses portal yang dipengaruhi oleh efikasi diri dan konten Instagram. Didapat nilai konstanta (a) sebesar 2,581 sedangkan variabel X1 (Efikasi Diri) memiliki nilai koefisien (b) sebesar 0,317 dan untuk variabel X2 (Konten Instagram) memiliki nilai koefisien 0,352. Sehingga dapat ditulis persamaan regresi berganda sebagai berikut:

$$
\mathrm{Y}=2,581+0,317 \mathrm{X} 1+0,352 \mathrm{X} 2
$$

Persamaan di atas menyatakan bahwa setiap kenaikan satu unit X1 (Efikasi Diri), maka nilai
Y (Minat Mengakses Portal) akan naik sebesar 0,317. Dan juga sebaliknya, apabila terjadi penurunan satu unit X1 (Efikasi Diri), maka nilai Y (Minat Mengakses Portal) akan menurun sebesar 0,317.

Kemudian untuk unit X2 (Konten Instagram), dapat dijelaskan bahwa setiap kenaikan satu unit X2 (Konten Instagram), maka nilai Y (Minat Mengakses Portal) akan naik 0,352 . Sedangkan bila terjadi penurunan satu unit X2 (Konten Instagram) maka nilai Y (Minat Mengakses Portal) mengalami penurunan sebesar 0,35 .

\section{Pengujian Hipotesa}

Tabel 13. Uji T (Parsial)

Coefficientsa

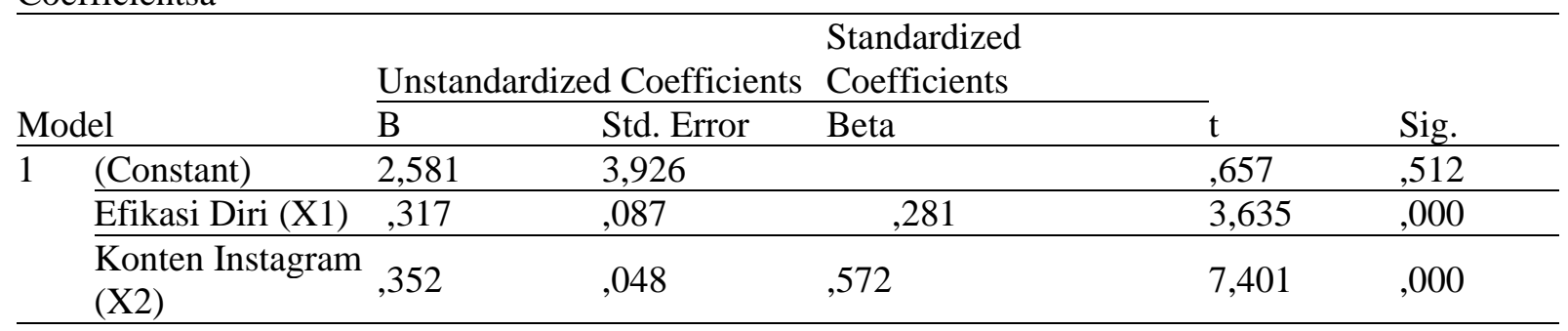

a. Dependent Variable: Minat Mengakses Portal

Dari Hasil uji t menyatakan bahwa nilai signifikan pada X1 (Efikasi Diri) adalah 0,00 yang berarti < (lebih kecil) dari nilai probabilitas yaitu 0,05 . Hal ini membuktikan bahwa H0 ditolak dan Ha diterima, maka dinyatakan bahwa terdapat pengaruh yang signifikan antara Efikasi Diri terhadap Minat Mengakses Portal Rumah Belajar. 
Tabel 14. Uji Annova (Simultan)

\begin{tabular}{|c|c|c|c|c|c|c|}
\hline \multicolumn{7}{|c|}{ ANOVAa } \\
\hline Model & & Sum of Squares & $\mathrm{df}$ & Mean Square & $\mathrm{F}$ & Sig. \\
\hline \multirow[t]{3}{*}{1} & Regression & 2346,270 & 2 & 1173,135 & 63,760 &, $000 \mathrm{~b}$ \\
\hline & Residual & 1784,720 & 97 & 18,399 & & \\
\hline & Total & 4130,990 & 99 & & & \\
\hline
\end{tabular}

a. Dependent Variable: Minat Mengakses Portal

ANOVAa

\begin{tabular}{|c|c|c|c|c|c|c|}
\hline \multirow{4}{*}{$\frac{\text { Model }}{1}$} & & Sum of Squares & $\mathrm{df}$ & Mean Square & $\mathrm{F}$ & Sig. \\
\hline & Regression & 2346,270 & 2 & 1173,135 & 63,760 &, $000 \mathrm{~b}$ \\
\hline & Residual & 1784,720 & 97 & 18,399 & & \\
\hline & Total & 4130,990 & 99 & & & \\
\hline
\end{tabular}

a. Dependent Variable: Minat Mengakses Portal

Tabel Annova di atas menyatakan bahwa nilai signifikan sebesar 0,000 yang berarti < (lebih kecil) dari nilai probabilitas yaitu 0,05 . Hal ini membuktikan bahwa $\mathrm{HO}$ ditolak dan $\mathrm{Ha}$ diterima, maka dinyatakan bahwa terdapat pengaruh yang signifikan secara simultan (bersama-sama) antara Efikasi Diri dan Konten Instagram Rumah Belajar terhadap Minat Mengakses Portal Rumah Belajar.

\section{PEMBAHASAN}

Penelitian ini bertujuan untuk mengetahui adakah pengaruh Efikasi Diri dan Konten Instagram terhadap Minat Mengakses Portal Rumah Belajar Kemdikbud, serta mengetahui besar pengaruh tersebut. Responden pada penelitian ini sebanyak 100 orang yang merupakan followers Instagram yang merupakan pelajar SMA/SMKA serta mengetahui adanya portal Rumah Belajar Kemdikbud.

Hasil analisis regresi menunjukkan bahwa terdapat nilai korelasi dimana menurut Haq (2019) untuk mengetahui kekuatan hubungan antara dua variabel atau lebih dan besarnya pengarun yang disebabkan oleh variabel bebas terhadap variabel terikat. Dalam penelitian ini korelasi secara parsial antara variabel efikasi diri berpengaruh secara positif, cukup kuat dan signifikan terhadap variabel minat mengakses portal Rumah Belajar sebesar 0,569 dan nilai signifikan adalah 0,00 hal ini membuktikan bahwa H01 ditolak dan Hal diterima, maka dinyatakan bahwa terdapat pengaruh yang signifikan antara Efikasi Diri terhadap Minat Mengakses Portal Rumah Belajar. Menurut Evaliana (2015) Efikasi diri memiliki peran penting dalam menumbuhkan minat dan menurut Shofiyah (2018) dimana efikasi diri memiliki peran penting dalam menumbuhkan minat karena semakin tinggi efikasi dirinya maka semakin tinggi minat seseorang dalam melakukan hal tersebut dengan kemampuannya. Hal ini sesuai karena pada penelitian ini menunjukkan adanya hubungan yang cukup kuat antara efikasi diri terhadap minat mengakses portal Rumah Belajar Kemdikbud.

Korelasi parsial antara variabel Konten Instagram terhadap variabel Minat Mengakses Portal mempunyai nilai sebesar 0,714 . Nilai ini menunjukkan terdapat hubungan yang kuat positif antara X2 dan Y dimana terjadi hubungan yang searah dan nilai signifikan pada Konten Instagram adalah 0,00 , Hal ini membuktikan bahwa $\mathrm{H} 02$ ditolak dan $\mathrm{Ha} 2$ diterima, maka dinyatakan bahwa terdapat pengaruh yang signifikan antara Konten Instagram terhadap Minat Mengakses Portal Rumah Belajar. Menurut Margaretha \& Sunarya (2017) konten merupakan teknik untuk membuat dan mendistribusikan nilai, relevansi, dan konsistensi sebuah informasi yang visual untuk menarik dan memperoleh target khalayak. Dan menurut Indika \& Jovita (2017) dimana minat beli dipengaruhi oleh media sosial yang 
dilakukan melalui persepsi konsumen terhadap produk. Hail ini sesuai karena pada penelitian ini menunjukkan adanya hubungan yang kuat antara konten Instagram Rumah Belajar terhadap minat mengakses portal Rumah Belajar Kemdikbud.

Adapun korelasi (R) yang secara simultan (bersama-sama) antara variabel X1 (Efikasi Diri) dan X2 (Konten Instagram) terhadap Y (Minat Mengakses Portal) diperoleh nilai sebesar 0,754. Nilai ini menunjukkan terdapat hubungan yang kuat positif antara $\mathrm{X} 1, \mathrm{X} 2$, dan $\mathrm{Y}$ dimana terjadi hubungan yang searah. Artinya bila X1 (Efikasi Diri) dan X2 (Konten Instagram) naik, maka Y (Minat Mengakses Portal) akan naik secara signifikan. Terbukti dari nilai signifikan sebesar 0,000 menyatakan $\mathrm{H} 03$ ditolak dan $\mathrm{Ha} 3$ diterima dan terdapat pengaruh yang signifikan secara simultan (bersama-sama) antara Efikasi Diri dan Konten Instagram Rumah Belajar terhadap Minat Mengakses Portal Rumah Belajar. Dikaitkan dengan pengertian minat oleh Lee \& Kotler (2015) bahwa "minat beli merupakan sesuatu yang timbul setelah menerima rangsangan dari produk yang dilihat individu, darisana muncul ketertarikan untuk mencoba produk tersebut sampai pada menimbulkan rasa keinginan untuk membeli agar dapat memilikinya", pengertian ini sejalan dengan Evaliana (2015) dimana minat secara garis besar dipengaruhi oleh faktor intrinsik dan faktor ektrinsik. Hal-hal ini sesuai karena pada penelitian ini menunjukkan adanya hubungan secara simultan antara efikasi diri dan konten Instagram Rumah Belajar terhadap minat mengakses portal Rumah Belajar Kemdikbud.

Adapun kontribusi atau sumbangan secara simultan yang diberikan oleh variabel X1 (Efikasi Diri) dan X2 (Konten Instagram) terhadap Y (Minat Mengakses Portal) mempunyai nilai sebesar 56,8\% (R Square), sedangkan sisanya $43,2 \%$ dipengaruhi oleh variabel lain. Hal ini menjelaskan bahwa Efikasi Diri dan Konten Instagram berdampak kuat dalam mempengaruhi minat mengakses portal Rumah Belajar Kemdikbud, khususnya di masa pandemik Covid-19 saat ini.

Hasil tabel koefisien menunjukkan hasil nilai konstanta yang diperoleh adalah 2,581, nilai koefisien X1 adalah 0,317, dan nilai koefisien $\mathrm{X} 2$ adalah 0,352 . Hal ini menunjukkan besarnya pengaruh Efikasi Diri (X1) terhadap Minat Mengakses Portal Rumah Belajar (Y) adalah 0,317 , yang berarti setiap kenaikan satu unit X1 (Efikasi Diri), maka nilai Y (Minat Mengakses Portal) akan naik sebesar 0,317. Dan besarnya pengaruh Konten Instagram (X2) terhadap Minat Mengakses Portal Rumah Belajar Kemdikbud adalah 0,352 , yang berarti setiap kenaikan satu unit X2 (Konten Instagram), maka nilai Y (Minat Mengakses Portal) akan naik sebesar 0,352 .

Dalam pengujian hipotesa secara parsial dimana $\mathrm{H} 1$ didapat hasil uji t dinyatakan nilai signifikan 0,00 dan lebih kecil dari nilai probabilitias 0,05 maka $\mathrm{HO}$ ditolak dan Ha diterima sehingga dinyatakan terdapat pengaruh yang signifikan antara efikasi diri terhadap minat mengakses portal Rumah Belajar. Pada pengujian hipotesa secara parsial dimana $\mathrm{H} 2$ didapat hasil uji $\mathrm{t}$ dinyatakan nilai signifikan 0,00 dan lebih kecil dari nilai probabilitas 0,05 maka $\mathrm{H} 0$ ditolak dan $\mathrm{Ha}$ diterima sehingga dinyatakan terdapat pengaruh signifikan antara konten Instagram Rumah Belajar terhadap minat mengakses portal Rumah Belajar.

Variabel Efikasi Diri (X1) dan Konten Instagram (X2) secara simultan (bersama-sama) berpengaruh terhadap Minat Mengakses Portal (Y) karena nilai signifikan sebesar 0,00 dan lebih kecil dari nilai probabilitas 0,05 . Hal ini membuktikan bahwa $\mathrm{H} 0$ ditolak dan Ha diterima sehingga terdapat pengaruh signifikan secara simultan (bersama-sama) antara Efikasi Diri (X1) dan Konten Instagram (X2) terhadap Minat Mengakses Portal (Y).

Dalam penelitian ini, variabel X1 yakni Efikasi Diri memiliki 3 dimensi, Level, Strength, dan Generality. Hasil analisa indikator dari variabel Efikasi Diri rata-rata jawaban responden sebesar 3,97\%. Sehingga disimpulkan bahwa efikasi diri yang dimiliki 
responden tergolong baik. Pada dimensi variabel $\mathrm{X} 1$ terdapat 3 dimensi. Dimensi Level, memiliki 2 indikator yakni menghadapi rintangan sebaik mungkin dan tidak mudah menyerah saat menghadapi persoalan yang sulit. Portal Rumah Belajar menyediakan sarana untuk peserta didik/responden sehingga responden merasa setuju bahwa jika dengan mengakses portal Rumah Belajar maka dapat menghadapi persoalan-persoalan yang sulit dalam pembelajaran, ini memberi pengaruh untuk mendorong peserta didik dalam minat mengakses portal Rumah Belajar. Dimensi Strength, memiliki 2 indikator yaitu selalu bersemangat mencapai hasil yang maksimal dan optimis dalam mengerjakan sesuatu. Melalui hasil penelitian responden menyatakan setuju dengan mengakses portal Rumah Belajar akan meningkatkan rasa semangat dan optimisme dalam belajar. Dimensi Generality, memiliki indikator-indikator yaitu seberapa yakin terhadap kemampuan diri, mengevaluasi diri menjadi lebih baik, bangkit kembali jika mengalami kegagalan, siap menghadapi resiko, bertanggung jawab dan melakukan perencanaan atas segala sesuatu yang dilakukan. Dan dari rata-rata jawaban responden menyatakan setuju dan ini membuktikan para peserta didik memiliki efikasi diri yang baik. Hal ini dapat ditunjukkan bahwa peserta didik yakin pada kemampuan dirinya, kegagalan yang ia alami dapat dijadikan pelajaran, serta selalu merencanakan apa yang dibutuhkan saat belajar untuk mencapai target.

Selaras dengan penelitian Evaliana (2015) dimana efikasi diri berhubungan dengan keyakinan bahwa diri memiliki kemampuan melakukan tindakan yang diharapkan. Pendapat Muhid \& Mukarromah (2018) juga selaras dimana efikasi diri sebagai kepercayaan individu akan kemampuannya untuk mengontrol fungsi dirinya dan terhadap lingkungan sekitarnya. Pernyataan responden setuju bahwa dengan mengakses Rumah Belajar akan meningkatkan efikasi dirinya dan percaya mampu mencapai hasil yang maksimal. Penelitian ini selaras dengan pendapat Saragih et al. (2020) bahwa efikasi diri terdiri dari faktor-faktor mastery experience (pengalaman keberhasilan), social modelling (pengalaman orang lain), social persuasion (persuasi sosial), dan physical and emotional states (emosi yang dirasakannya). Dari jawaban responden diketahui bahwa efikasi diri yang diperoleh selain dari mengakses Rumah Belajar yaitu dengan kemampuan yang tidak mudah menyerah, bertanggung jawab atas hal yang dilakukan dan merencanakan segala sesuatu yang dibutuhkan dalam diri responden untuk mencapai hasil yang diinginkan. Rata-rata responden termotivasi dengan mengakses portal Rumah Belajar akan meningkatkan dalam hal pembelajaran sehingga meningkatkan efikasi dirinya.

Variabel X2 yakni Konten Instagram memiliki 3 dimensi, Valuable, Relevant, dan Consistent. Hasil analisa indikator dari variabel Konten Instagram rata-rata jawaban responden sebesar 3,80\%. Sehingga disimpulkan bahwa Konten Instagram pada akun Rumah Belajar tergolong baik bagi para responden. Dimensi Valuable, memiliki 5 indikator yakni post foto menarik, post video menarik, caption yang informatif, Hashtag yang digunakan bernilai, dan tatanan feeds yang menarik. Rata-rata responden menyatakan bahwa konten Instagram yang diunggah mempunyai nilai nyata yang bermanfaat, menarik, dan informatif sehingga penelitian ini selaras dengan pendapat Herlina (2018) yang menyatakan konten adalah sesuatu yang mempunyai atau menambahkan nilai kepada hidup pembaca. Deiss \& Henneberry (2020) menyatakan bahwa konten yang bagus adalah menambahkan nilai ke khalayak dan adanya percakapan online, walaupun responden menyatakan ragu-ragu terhadap pernyataan untuk mengomentari unggahan akun Rumah Belajar namun responden menyatakan setuju untuk menyukai dan menilai konten yang diunggah sehingga responden pun tertarik untuk mengakses portal Rumah Belajar.

Variabel Y, minat mengakses portal memiliki 5 dimensi, yaitu tertarik untuk mencari 
informasi tentang portal, mempertimbangkan untuk mengakses portal, tertarik untuk mencoba portal, ingin mengetahui portal, dan ingin mengakses portal. Hasil analisa indikator dari variabel minat mengakses portal rata-rata jawaban responden sebesar 4,04\%. Sehingga disimpulkan bahwa responden mempunyai minat untuk mengakses portal Rumah Belajar yang cukup baik. Minat mengakses portal Rumah Belajar sudah tinggi jika dilihat dari respon atas konten Instagram yang diunggah di akun Instagram Rumah belajar, Responden merasa percaya bisa meningkatkan efikasi dirinya dengan mengakses portal, tertarik karena portal Rumah Belajar adalah bimbingan belajar online yang gratis, kemudahan untuk akses di mana saja dan kapanpun, portal Rumah Belajar yang sudah menggunakan fitur-fitur teknologi 4.0, pendapat lingkungan dari teman, keluarga, dan guru, ditambah pula dengan pandemik COVID-19 saat ini peran Rumah Belajar sangat membantu sehingga responden tertarik untuk berminat mengakses portal Rumah Belajar.

Penelitian ini selaras dengan pendapat Lee \& Kotler (2015) menyatakan bahwa minat beli merupakan sesuatu yang timbul setelah menerima rangsangan dari produk yang dilihat individu, darisana muncul ketertarikan untuk mencoba produk tersebut sampai pada menimbulkan rasa keinginan untuk membeli agar dapat memilikinya. Selaras terhadap penelitian Evaliana (2015) Minat secara garis besar dipengaruhi oleh dua faktor yaitu faktor intrinsik dan faktor ektrinsik. Diperkuat dengan pernyataan Fatimah \& Naryoso (2019) faktorfaktor yang mempengaruhi minat mengakses diantaranya ada faktor internal dan faktor eksternal. Adapun dalam penelitian ini, responden menyatakan setuju untuk tertarik minat mengakses portal Rumah Belajar akan meningkatkan efikasi dirinya sebagai faktor internal, dan tertarik minat mengakses portal Rumah Belajar karena unggahan konten Instagram Rumah Belajar sebagai faktor eksternal. Selain itu berdasarkan hasil analisa indikator responden tentang frekuensi penggunaan Instagram sebesar $61 \%$ responden menggunakan Instagram setiap harinya juga mempengaruhi minat mengakses portal Rumah Belajar karena terpaparnya konten-konten yang diunggah oleh akun Instagram Rumah Belajar.

\section{KESIMPULAN}

Kesimpulan dari hasil penelitian ini bahwa pengaruh Efikasi Diri dan Konten Instagram Rumah Belajar terhadap Minat Mengakses portal Rumah Belajar Kemdikbud, adalah sebagai berikut.

1. Adanya pengaruh yang positif dan signifikan pada efikasi diri terhadap minat mengakses portal Rumah Belajar karena didapat nilai signifikansi 0,00 dan lebih kecil dari nilai probabilitas 0,05 berarti $\mathrm{Ha} 1$ diterima. Besarnya pengaruh efikasi diri terhadap minat mengakses portal Rumah Belajar adalah sebesar 0,317.

2. Adanya pengaruh yang positif dan signifikan pada konten Instagram terhadap minat mengakses portal Rumah Belajar karena didapat nilai signifikansi 0,00 dan lebih kecil dari nilai probabilitas 0,05 berarti $\mathrm{Ha} 2$ diterima. Besarnya pengaruh konten Instagram terhadap minat mengakses portal Rumah Belajar adalah sebesar 0,352.

3. Hasil perhitungan uji annova mendapat nilai signifikan sebesar 0,000 dimana lebih kecil dari nilai signifikansi 0,05 berarti bahwa $\mathrm{Ha} 3$ diterima, maka terdapat adanya pengaruh signifikan antara Efikasi Diri dan Konten Instagram Rumah Belajar terhadap Minat Mengakses portal Rumah Belajar Kemdikbud dengan nilai kontribusi sebesar $56,8 \%$.

\section{DAFTAR PUSTAKA}

Agussani, A. (2020). Dampak Pendidikan 4.0 Terhadap Kehidupan Sosial di Lingkungan Kampus. In Kumpulan Penelitian dan Pengabdian ....

Deiss, R., \& Henneberry, R. (2020). Digital Marketing For Dummies®, 2nd Edition. 
In Africa's potential for the ecological intensification of agriculture.

Evaliana, Y. (2015). Pengaruh Efikasi Diri Dan Lingkungan Keluarga Terhadap Minat Berwirausaha Siswa. Jurnal Pendidikan Bisnis Dan Manajemen.

Fatimah, Z. A., \& Naryoso, A. (2019). Hubungan Antara Intensitas Mengakses Informasi Pariwisata Akun Instagram @Indtravel Dan Intensitas Komunikasi Word Of Mouth Dengan Minat Wisatawan Mancanegara Berkunjung Ke Indonesia. Interaksi Online UNDIP.

Haq, S. W. (2019). Pengaruh Terpaan Tayangan Drama Korea Terhadap Keputusan Pembelian Produk Kuliner Korea. Ilmu Komunikasi.

Herlina, L. (2018). DISINTEGRASI SOSIAL DALAM KONTEN MEDIA SOSIAL FACEBOOK. TEMALI: Jurnal Pembangunan Sosial. https://doi.org/10.15575/jt.v1i2.3046

Indika, D. R., \& Jovita, C. (2017). MEDIA SOSIAL INSTAGRAM SEBAGAI SARANA PROMOSI UNTUK MENINGKATKAN MINAT BELI KONSUMEN. Jurnal Bisnis Terapan. https://doi.org/10.24123/jbt.v1i01.296

Kartika, S., Husni, H., \& Millah, S. (2019). Pengaruh Kualitas Sarana dan Prasarana terhadap Minat Belajar Siswa dalam Pembelajaran Pendidikan Agama Islam. Jurnal Penelitian Pendidikan Islam. https://doi.org/10.36667/jppi.v7i1.360

Khotimah, R., Radjah, C., \& Handarini, D. (2016). HUBUNGAN ANTARA KONSEP DIRI AKADEMIK, EFIKASI DIRI AKADEMIK, HARGA DIRI DAN PROKRASTINASI AKADEMIK PADA SISWA SMP NEGERI DI KOTA MALANG. Jurnal Kajian Bimbingan Dan Konseling. https://doi.org/10.17977/um001v1i22016 p060

Lee, N. R., \& Kotler, P. (2015). Social marketing: Changing behaviors for good. $N A$.

Margaretha, L., \& Sunarya, D. M. (2017). INSTAGRAM SEBAGAI MEDIA SOSIALISASI 9 PROGRAM
UNGGULAN PEMERINTAH (Studi Kasus pada Bagian Hubungan Masyarakat Kementrian Koperasi dan Usaha Kecil dan Menengah Republik Indonesia pada Instagram @kemenkopUKM)._Communication. https://doi.org/10.36080/comm.v8i2.637

Muhid, A., \& Mukarromah, A. (2018). Pengaruh Harapan Orang Tua dan SelfEfficacy Akademik terhadap Kecenderungan Fear of Failure pada Siswa: Analisis Perbandingan antara Siswa Kelas Unggulan dan Siswa Kelas Reguler. Jurnal Darussalam: Jurnal Pendidikan, Komunikasi Dan Pemikiran Hukum Islam. https://doi.org/10.30739/darussalam.v10i 1.266

Mulyadi, M. (2012). RISET DESAIN DALAM METODOLOGI PENELITIAN Mohammad Mulyadi (. STUDI KOMUNIKASI DAN MEDIA.

Nia Safitri. (2019). Pendidikan Indonesia Menyongsong Era Revolusi 4.0. Www.Kompasiana.Com.

Nilasari, S. (2020). Pendidikan di Era Revolusi Industri 5.0 terhadap Disiplin Kerja Guru. Seminar Nasional Pendidikan Program Pascasarjana Universitas PGRI Palembang.

Prastihastari Wijaya, I. (2012). EFIKASI DIRI AKADEMIK, DUKUNGAN SOSIAL ORANGTUA DAN PENYESUAIAN DIRI MAHASISWA DALAM PERKULIAHAN. Persona:Jurnal Psikologi Indonesia. https://doi.org/10.30996/persona.v1i1.14

Risdianto, E. (2019). Analisis Pendidikan Indonesia di Era Revolusi Industri 4.0. In Research Gate.

Saragih, S. A., Menanti, A., \& Budiman, Z. (2020). Hubungan antara Self-Efficacy dan Dukungan Sosial dengan Coping Stress pada Petani Hortikultura dalam Mengelola Usaha Tani di Saribudolok. Tabularasa: Jurnal Ilmiah Magister Psikologi. https://doi.org/10.31289/tabularasa.v2i1. 288

Shafira \& Ira. (2020). Peran Konten Post 
Instagram Terhadap Keterlibatan Pelanggan Secara Daring Pada Industri Kosmetik Di Indonesia. Nasional, Seminar Riset, Terapan Series, Isas Publishing Vol, Science.

Shofiyah, S. (2018). Prinsip - Prinsip Pengembangan Kurikulum dalam Upaya Meningkatkan Kualitas Pembelajaran. EDURELIGIA; JURNAL PENDIDIKAN AGAMA ISLAM. https://doi.org/10.33650/edureligia.v2i2. 464

Sudaryono, S., Sunarya, L., \& Maulani, G. (2018). Facility for Customizing Transaction Forms on Master Data Using an Online Accounting System Web For Work Efficiency Company. Aptisi Transactions on Management (ATM). https://doi.org/10.33050/atm.v1i1.681

Suyitno. (2020). Analisis Data dalam Rancangan Penelitian Kualitatif. Akademika.

Wahyudin, D., \& Adiputra, C. P. (2019). ANALISIS LITERASI DIGITAL PADA KONTEN INSTAGRAM @INFINITYGENRE. WACANA, Jurnal Ilmiah Ilmu Komunikasi. https://doi.org/10.32509/wacana.v18i1.7 44

Wahyuni, S., Fourqoniah, F., \& Arsyad, A. W. (2019). Pengaruh Konten Instagram @Smrfoodies Terhadap Minat Beli Followers. EJournal Ilmu Komunikasi.

Yusnaini, \& Slamet. (2019). Era Revolusi Industri 4.0: Tantangan dan Peluang dalam Upaya Meningkatkan Literasi Pendidikan. Prosiding Seminar Nasional Pendidikan Program Pascasarjana Universitas Pgri Palembang. 